\title{
From Hot Cakes to Gold Feet: A Contingent Perspective on the Relationship between Market Uncertainty and Status Homophily in the Formation of Alliances
}

\section{Francois Collet and Déborah Philippe}

ESADE Business School, Ramon Llull University; University of Lausanne

ABSTRACT In this study, we reconsider the classical positive association between the level of market uncertainty and an organization's propensity to form ties with organizations of similar status. Although prior research argues that the greater the uncertainty, the higher the level of status homophily, we suggest that this relationship is contingent upon framing that affects positive or negative valence towards uncertainty. In an up market, organizations tend to frame uncertainty as upside risk, and thus will subsequently favour explorative uncertainty-mitigation devices; whereas, in a down market, organizations primarily frame uncertainty as downward risk, and thus will rely on more conservative uncertainty-mitigation mechanisms. We therefore predict that a greater number of status-heterophilous ties will be formed in an up market than in a down market. We discuss the implications of our results for status theory and more broadly for research on strategic decision making under uncertainty.

Keywords: alliance, decision making, framing, homophily, status, uncertainty

\section{INTRODUCTION}

Uncertainty has been widely documented as a driving force behind the formation of inter-organizational ties (Auster, 1992; Beckman et al., 2004; Pfeffer and Salancik, 1978). In research on strategic alliances, for instance, empirical studies suggest that organizations facing environmental uncertainty will partner with other organizations in an effort to share risks and acquire knowledge (Gulati, 1995a; Kogut, 1991; Luo, 1997). However, selecting an alliance partner represents a challenge in itself. Information regarding potential partners is highly valued but scarce and costly to obtain (Nohria, 1992); therefore, a key concern is to reduce uncertainty relative to potential partners' capabilities (Kogut, 1988) and trustworthiness (Gulati, 1995a). To cope with 
this dearth of information, market actors can rely on cues found in the surrounding social structure (Beckert, 1996; DiMaggio and Powell, 1983; Meuleman et al., 2010; Podolny, 1994).

Status constitutes one type of social cues that organizations can rely upon when selecting an alliance partner. The status of an organization can be defined as the prestige and recognition derived from its position in a hierarchical social structure (Gould, 2002; Podolny, 2005; Washington and Zajac, 2005). Actors who possess discriminating statusvalued characteristics (Ridgeway and Berger, 1986) have been shown to enjoy significant privileges (Gould, 2002).

Based on the assumption that quality is to some extent positively related to status, status cues can discriminate among organizations when quality is difficult to observe (Podolny, 2005). Podolny (2001) highlights the role of interorganizational relationships as status signals and conceptualizes these relationships as 'prisms' through which external audiences perceive a focal organization. According to this prism perspective, observers infer an organization's intrinsic quality from the status of the organizations it is connected to (Benjamin and Podolny, 1999; Podolny, 2001; Washington and Zajac, 2005) because the willingness of others to associate with the focal organization provides a means for evaluating its unobservable characteristics (Podolny, 1994; Podolny and Phillips, 1996).

An important claim of this relational view of status is that the manifest transfer of resources (i.e. goods or services) is associated with a latent transfer of status between partners (Podolny and Phillips, 1996; Stuart et al., 1999). The formation of a relationship between a high-status actor and a low-status actor thus results in a loss of status for the former and a gain for the latter (Podolny, 1994, 2005). As a consequence, status anxiety - that is, the fear of being devalued because other market actors within the field doubt the quality of one's partners (Jensen, 2006) - leads organizations to enter and maintain relationships with partners of similar status (Chung et al., 2000; Podolny, 1994; Rosenkopf and Padula, 2008), a phenomenon known as status homophily.

Prior research has shown that the value granted to status signals depends on the level of market uncertainty confronted by organizations. In the face of market uncertainty, which cannot be controlled by a single organization (Beckman et al., 2004), the complexity of the partner-selection process increases and the social structural position of potential partners is used as a signal of quality. Consequently, the higher this uncertainty, the greater the importantce of status, and the greater the inclination of organizations to form homophilous ties (Podolny, 1994). As demonstrated in recent studies, however, certain conditions can override this inclination to form homophilous ties. For instance, high-status organizations may be willing to initiate ties with organizations of lower status when they believe they can extract greater effort and commitment from low-status partners (Castellucci and Ertug, 2010) or when they expect heterophilous ties to yield informational benefits (Shipilov et al., 2011). Building on these studies, and in contrast to prior research on status that posits a linear relationship between market uncertainty and the value of status signals as substitutes to unobservable quality, we propose a more nuanced vision of the classical positive association between the level of market uncertainty and an organization's propensity to form homophilous ties. Specifically, we argue 
that the value of status signals varies, depending upon the context in which organizations are embedded.

We advance research on the contingent nature of decision-making processes, and, in particular, upon works showing how context can differentially channel attention and decision making (Gulati and Higgins, 2003; Joseph and Ocasio, 2012; Ocasio, 1997, 2011; Sullivan, 2010), by showing that different market conditions frame the perception of the relative value of status signals and therefore influence the type of relationships organizations initiate (i.e. homophilous versus heterophilous ties). We consider two market conditions to study the alliance partner-selection process: an up market, dominated by an emphasis on upside risk (i.e. where uncertainty is framed in terms of potential opportunities), and a downward market, where downside risk prevails (i.e. where uncertainty is framed in terms of possible losses). We propose that in up markets, organizations primarily focus on not missing good partnerships and pay less attention to status cues in their partner-selection process, while in downward markets, organizations are mostly concerned with avoiding initiating ties with unworthy partners and therefore rely heavily on status cues as their primary uncertainty-mitigation device. As a consequence, we expect status homophily to be relatively higher in downward markets than in up markets. In addition, we predict that even in the face of increased market uncertainty, this difference in organizations' propensity to engage in or, on the contrary, to refrain from, initiating heterophilous ties will hold and even increase. Our empirical analyses provide support for our conjectures that different framings of uncertainty affect the relative importance of status in alliance-formation processes.

We test our hypotheses in the context of alliance formation in the software industry during the period 1996 to 2002. The software industry provides a particularly interesting empirical setting because it comprises two very distinct up market and down market phases. From the mid-1990s until the middle of 2000, the market followed a strong upward trend fuelled by the diffusion of computer network technology to a large audience (Cassidy, 2002). This first period has been dubbed 'the internet bubble' or 'the dot-com bubble', and was heralded, at the time, as the start of a 'new economy', free from traditional economic cycles. Although most internet firms never became profitable, many that pursued initial public offerings were highly successful. This first expansionary period was followed by a phase of contraction, during which numerous firms collapsed and investors incurred substantial losses. Thus, this empirical setting provides a site to test actors' responses to exceptional levels of market uncertainty, during both the speculative up market phase and the steep down market period that followed.

Our paper is structured as follows. In the next section, we review the literature on the relationship between status homophily and market uncertainty. We then discuss how contextual elements and their subsequent framing may affect the level of status homophily and its relationship with market uncertainty, from which we derive testable hypotheses. After analysing our data on the software industry, we present and elaborate on our findings. We conclude the paper with a discussion of the implications and contributions of our study to research on status and on decision-making under uncertainty. 


\section{THEORY AND HYPOTHESES}

\section{Uncertainty and Status Homophily}

Uncertainty is a central concept in organizational theory (March and Simon, 1958). At the organizational level, uncertainty, defined as the 'difficulty firms have in predicting the future, which comes from incomplete knowledge' (Beckman et al., 2004, p. 260), characterizes situations where actors cannot anticipate or predict future states of the world (Pfeffer and Salancik, 1978). Under conditions of uncertainty, imperfect information prevents actors from knowing how to behave and what to expect from their environment (Hogg and Terry, 2000). Such uncertainty, which cannot be controlled by any direct organizational action, is termed 'market uncertainty' (Beckman et al., 2004, p. 262). Market uncertainty is shared by all organizations within a given field and encompasses a wide range of issues, such as instability in consumer demands for products and services or increased levels of industry concentration. To mitigate this uncertainty, organizations may seek to establish partnerships with other actors (Auster, 1992; Beckman et al., 2004; Gulati, 1995a; Luo, 1997; Pfeffer and Salancik, 1978).

Although associating with an exchange partner might enable an organization to mitigate some effects of market uncertainty, selecting the appropriate alliance partner is itself a challenging and critical issue. Because organizations might not be able to effectively evaluate potential partners prior to a collaboration, a key issue in the selection process is to reduce uncertainty relative to the potential partners' capabilities (Kogut, 1988) and trustworthiness (Gulati, 1995a). Organizations willing to mitigate this selection uncertainty will turn to their surrounding social structures to seek cues (Haunschild, 1994; Podolny, 1994; Powell and DiMaggio, 1983) that will enable them to make decisions by substituting 'simpler judgmental operations' for 'complex tasks of assessing probabilities and predicting values' (Tversky and Kahneman, 1974 p. 1124). As amply demonstrated in prior research (e.g. Podolny, 2005), when information is scarce or is overabundant and noisy, organizations rely heavily on status signals as cues to evaluate the quality of potential partners' output. Status can be defined as the amount of prestige, recognition, and privilege granted to an organization given its position in a hierarchical social structure (Gould, 2002; Podolny, 2005; Washington and Zajac, 2005).

In recent years, a substantial stream of research has explored the dynamics underlying status-based stratifications. Status-based models of market competition posit that because market actors can derive significant benefits from an incremental increase in status (Park and Podolny, 2000), they will engage in behaviours that maintain or enhance their own status. According to a fundamental claim of this stream of research, in a marketexchange relationship, the manifest transfer of resources (i.e. goods or services) is associated with a latent transfer of status between exchange partners (Jensen, 2004; Podolny and Phillips, 1996; Stuart et al., 1999). Organizational fields are thus relationally negotiated orders where an organization's status position is contingent on the status of its affiliates (Podolny and Phillips, 1996), and status dynamics are traditionally explained in terms of changes in an organization's pattern of market ties (Podolny, 2001; Podolny and Phillips, 1996). A central concern has thus been to investigate the impact on status of affiliating with others. For instance, in their study of the US intercollegiate postseason basketball tournament, Washington and Zajac (2005) documented this 'leaking' 
characteristic of status by suggesting both that status evolution is a function of the accumulation of positive and negative associations, and that status can be transferred through both cooperative and competitive relationships. They find that, regardless of a team's performance during the game, competing with high-status schools enhances a team's status, while competing with low-status schools erodes status.

As evidenced in the above-mentioned study, when organizations with dissimilar status positions share a tie, the higher-status organizations suffer from status erosion, while their lower-status partners experience status growth (Podolny, 1994; Podolny and Phillips, 1996). As a consequence, an affiliation can lead to an alteration of the privileges afferent to a particular status position. Because of 'status anxiety' (Jensen, 2006), organizations are thus reluctant to associate with lower-status counterparts and instead tend to adopt a principle of exclusivity in their partner-selection process. That is, they elect to engage in relationships with organizations of approximately similar status, a phenomenon known as status homophily (Chung et al., 2000; McPherson and Smith-Lovin, 1987; McPherson et al., 2001; Podolny, 1994; Rosenkopf and Padula, 2008). Thus, a central assumption of status research is that the greater the market uncertainty, the greater organizations' reliance on status signals to make decisions, and, subsequently, the greater the likelihood that these organizations will initiate status homophilous ties (Podolny, 1994).

Only recently have scholars challenged this assumption, showing that, in certain conditions, status-based heterophilous ties may be preferred over homophilous ties. For instance, in their study of the Formula One industry, Castellucci and Ertug (2010) build on the idea that organizations are willing to pay a tribute in exchange for status gains and find that high-status racing teams can therefore secure greater efforts from low-status engine suppliers than from engine suppliers of similar status. This extraction of greater efforts, in turn, confers a positive effect on team performance. Similarly, Shipilov et al. (2011) argue that some organizations are more likely than others to build heterophilous ties. For example, an organization that occupies a brokerage position within a network (i.e. bridging otherwise unconnected partners) is more likely than others to initiate status heterophilous ties, but only when its achieved performance exceeds its own performance aspirations. Initiating heterophilous ties allows this organization to extract higher tribute from its lower-status partners or to reduce its own tribute extended to its higher-status associates. Thus, in some occasions, organizations may consider the loss of status engendered by their associations with lower-status partners to be amply compensated by the benefits extracted as a result of the association.

In this paper, we build on these studies to reconsider the classical positive association between the level of market uncertainty and an organization's propensity to favour homophilous ties. However, our perspective differs from these studies in one fundamental way. We do not explain the propensity of some organizations to engage in status-heterophilous ties as being motivated solely by the search for organizational benefits but as the consequence of the framing of the context in which these organizations are embedded. The theoretical underpinning for our central claim is the proposition that different market conditions focus organizations' attention on different types of concerns, thus affecting their propensity to form status-homophilous ties. 


\section{Environmental Gonditions, Differentiated Framings, and Status Homophily}

Environmental conditions and strategic decisions. Organizations' decisions and behaviours are shaped by the issues and concerns they focus on. Actors can use different frames, or 'schemata of interpretation', to help make sense of events and occurrences (Goffman, 1974; Snow et al., 1986). The selective encoding of elements (Williams and Benford, 2000) leads actors to attend more acutely to particular issues (Fiss and Zajac, 2006), thereby affecting their decision-making process.

A central postulate of several streams of research in organization theory is the reference-dependent nature of actors' behaviours. With a particular focus on risk-taking and risk-reduction behaviours, research inspired by the behavioural theory of the firm (Argote and Greve, 2007; Gyert and March, [1963] 1992; Gavetti et al., 2007; Greve, 1999, 2003; Shinkle, 2012) has shown that the discrepancy between the level of performance actors aspire to achieve and their actual achieved performance frames and guides their strategic behaviour. In a similar fashion, works that build on strategic reference point theory (Fiegenbaum and Thomas, 1986, 1988; Fiegenbaum et al., 1996; Shoham and Fiegenbaum, 2002), which is largely inspired by prospect theory (Kahneman and Tversky, 1979; Tversky and Kahneman, 1981), suggest that actors are risk-averse when their performance is above a reference point, but tend to be risk-taking when their performance falls short of this reference point. These responses are partly due to actors' tendency to frame issues as threats when their performance exceeds their reference point, and as opportunities when their performance fails to meet their reference point (Shinkle, 2012).

These streams of research have deepened our understanding of the contingent nature of decision-making processes; however, less is known about the role of the external environment in the framing and shaping of organizational behaviour. As recently suggested by researchers who contribute to the behavioural theory of the firm, future research should therefore 'elaborate further the impact of situational context on decision making to account for a number of variables, including decision framing' (Gavetti et al., 2007, p. 532).

Consistent with this call, 'neo-Carnegie' attention-based research shows that the particular contexts actors find themselves in can differentially focus and shape their attention and decision making (Gulati and Higgins, 2003; Joseph and Ocasio, 2012; Ocasio, 1997, 2011; Sullivan, 2010). ${ }^{[1]}$ Gulati and Higgins (2003), for instance, propose that the uncertainty faced by investors is framed differently, depending on the favourability of equity markets. In a similar vein, behavioural finance research shows that market directions can be construed as frames shaping actors' behaviours (Docking and Koch, 2005). Docking and Koch show that investors' positive reaction to financial performance that exceeds expectations is amplified when the market is volatile and moving upward, whereas negative reactions to results that fall short of expectations are magnified when the market is volatile and moving downward. We build on these findings to investigate the extent to which organizations' emphasis on status signals in their partner-selection process is framed by the market conditions these organizations confront. 
Prior research has defined uncertainty as the variance in the distribution of potential outcomes, arguing that it may manifest in terms of upside risk (i.e. uncertainties that can have positive outcomes) or downside risk (i.e. uncertainties that can have negative outcomes) (March and Shapira, 1987; Miller and Leiblein, 1996; Miller and Reuer, 1996; Reuer and Leiblein, 2000). Based on this distinction, we consider two types of market conditions for studying the partner-selection process: an up market, characterized by upside risk, and a down market, where downside risk prevails.

The selection of an alliance partner entails two main concerns for the partner-seeking organization: the failure to notice valuable partners and, on the contrary, the selection of low-value partners. Although both concerns likely affect any partner-selection process, we suggest that partner-seeking organizations will tend to focus on, and therefore attend to, one concern or the other, depending on whether market conditions are upward or downward. In high-growth, expansionary phases (up markets), where products and services are expected to 'sell like hot cakes', organizations channel their attention towards identifying the most promising developments. Because upside risk prevails in up markets, opportunities are positively valenced (i.e. they are framed as being attractive), typically leading organizations to engage in exploration and trial-and-error processes. Failures are thus likely to be perceived as having limited consequences for an organization's future. As a result, during expansionary phases, organizations will be less concerned by the risk of selecting the wrong partners and will, instead, tend to engage in developing partnerships that are promising, although uncertain. In such contexts, organizations will seek to build new and diverse ties in an effort to access novel resources and knowledge, even when the prospects of some alliances may be doubtful (see Burt, 2005 for a synthetic argument on vision; see also Owen-Smith and Powell, 2004, 2008; Powell et al., 2005). The expected benefits that can be extracted from these new and diverse ties are likely to defuse, at least in part, the status anxiety (Jensen, 2006) that these organizations may experience (Shipilov et al., 2011).

By contrast, in a contractive phase (a down market), when market confidence is damaged, organizations' attention is primarily channelled towards not making bad deals. Because downside risk prevails, opportunities are negatively valenced (i.e. they are framed as being unattractive). Organizations thus tend to have 'cold feet' and refocus their investments to activities whose benefits can be easily measured and observed, in an effort to avoid a poor allocation of their resources. Organizations no longer have the incentive of forming ties outside their status bracket for the purpose of building a diverse set of relationships. Instead, they will rely on established formulas and players, which are seen as providing a refuge. A central concern becomes the potential damage that may be caused by an association with actors that have been significantly affected by the downturn. Thus, status signals are likely to be used to reduce the uncertainty surrounding the evaluation of potential partners. Further, status anxiety typically runs high, further reinforcing the effect of status in the formation of an alliance.

We therefore propose that, all things being equal (i.e. given similar levels of market uncertainty), organizations will grant higher value to status signals in down markets than in up markets. As a consequence, we should observe a higher level of status homophily in the down markets than in up markets. Hence, the following hypothesis: 
Hypothesis 1: The level of status homophily in alliance formation is lower in an up market than in a down market.

\section{Level of Market Uncertainty and Status Homophily}

Prior research on status-based models of market interactions posits that the higher the uncertainty confronted by actors, the greater these actors' reliance on status signals as substitutes for reliable information, and, therefore, the more likely they are to initiate status-homophilous ties (Podolny, 1993, 2005). We suggest that this underlying assumption of status research needs to be qualified and that the positive relationship between market uncertainty and status homophily is contingent on the market conditions confronted by organizations. By extending Hypothesis 1, which predicts that, at constant levels of uncertainty, organizations embedded in up market conditions should initiate fewer status-homophilous ties than organizations embedded in downward market conditions, we argue that these differences should hold and may even be reinforced when the level of market uncertainty varies.

In a down market, organizations will react to a rise in the level of market uncertainty by relying heavily on status signals when selecting an exchange partner. In such contractive phases, organizations are primarily concerned with entering into relationships with reliable partners; that is, organizations seek partners that will deliver on quality and will not send negative signals to their audiences. Higher levels of market uncertainty in a down market will not only amplify status anxiety but also increase organizations' vulnerability to environmental variations. Because partnering with lower-status actors incurs higher advertising, transaction, and financial costs (Fombrun and Shanley, 1990; Podolny, 1993), initiating status heterophilous ties increases the vulnerability of higherstatus organizations. In such contexts, status signals will therefore constitute valuable uncertainty-reduction mechanisms, and a rise in the level of market uncertainty will likely trigger the posited classical increase in the formation of homophilous ties.

In contrast, we predict that, in an up market, status signals (even when they continue to play a role in the partner-selection process) will be less attended to by organizations facing rising levels of market uncertainty. In such a context, identifying promising opportunities supersedes other concerns, leading to numerous strategies that may carry some downside risks being considered as adequate for two reasons. First, as evidenced by abundant research in strategy and network theory, forming new and diverse ties, independent of status, is a valuable way of coping with uncertainty and the constraints of dependency on others (Beckman et al., 2004; Gargiulo, 1993; Pfeffer and Salancik, 1978). Forming ties with new players provides an opportunity for learning about new practices and technologies (Baum et al., 2003; Davis and Greve, 1997; Podolny et al., 1996; Shipilov et al., 2011), thereby maximizing the probability that some partnerships will be successful. Rather than seeking partnerships with organizations of similar status, actors may be willing to form heterophilous ties in their effort to cope with rising levels of market uncertainty. Second, the status of established players may be put into question, as on some occasions, environmental changes may be associated with speculation regarding the status of incumbents and therefore will create opportunities for actors to make new types of status claims (Lounsbury, 2002). In expansionary phases, newcomers may 
attempt to challenge established status hierarchies by substituting new status signals for the existing ones. For these reasons, a rise in the level of market uncertainty should not trigger the expected increase in the formation of homophilous ties and may even increase the initiation of heterophilous ties. We thus make the following hypothesis:

Hypothesis 2: A rise in market uncertainty will lead to a rise in status homophily in alliance formation that is more accentuated in a down market than in an up market.

\section{METHODS}

\section{Empirical Context and Data}

We test our hypotheses in the software industry, where status signals are likely to play a role in the formation of strategic alliances between software organizations. The software industry is based on a series of successive innovations that generate a complex and changing technological ecosystem, making quality evaluations difficult (Campbell-Kelly, 1995, 2004; Cusumano, 2003, 2004). As a consequence, status signals may provide useful information for the process of selecting alliance partners. We collected data on software organizations tracked in the Dow Jones Global Software Index, which covers 95 per cent of the market capitalizations of software organizations. For the 216 publicly traded global software organizations included in the Dow Jones Global Software index, we collected financial data from Thomson One Banker, US Securities and Exchange Commission (SEG) filings, and Canadian Security Administrators for the period 1996-2002 and collected data on alliances from SDC and Factiva (Lavie, 2007).

In the software industry, the mid-1990s marked the rise of new technologies. The diffusion of internet-related technologies to a wide range of applications (e.g. e-commerce and e-mail) generated uncertainty in the software industry for two reasons. First, these technologies were 'disruptive' for incumbents (Christensen, 1997; Christensen et al., 2002). For example, the new Java programming language may not have run as fast as the previous $\mathrm{C}++$ technology used by many incumbents but provided attributes that made it relevant to internet applications at a performance level acceptable to most users (Christensen, 2000; Christensen et al., 2002). Second, the uncertainty generated by these technological transformations spurred a wave of speculative investments (Brunnermeier and Nagel, 2004; Ofek and Richardson, 2003) that exacerbated the tendency of markets to evolve into what Keynes called a 'beauty contest' in which actors 'devote [their] intelligence to anticipating what average opinion expects the average opinion to be’ (Keynes, [1936] 1958, chapter 12, p. 158). Mary Meeker, a former Morgan Stanley security analyst, the author of The Internet Report, and a highly influential internet security analyst, commented:

There is the same supply and demand imbalance [as during the Tulip bulb mania that struck Holland in the early seventeenth century], the difference is that Tulip bulb didn't fundamentally change the way companies do business. The Internet does. But when all is said and done there will be many stocks that in hindsight look like tulip-bulb stories. (Cassidy, 1999, p. 51) 


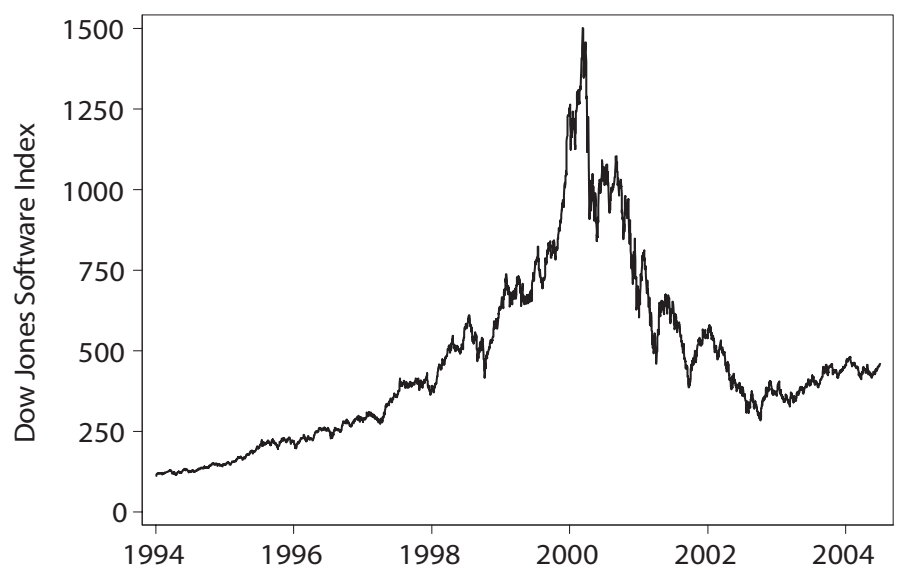

Figure 1. Dow Jones Software Index, 1994-2004

The wave of investments into internet-related technology ended in mid-2000 (Cassidy, 2002), when many start-ups that had attracted large investments collapsed, subsequently affecting the entire software industry. Figure 1 shows how the market, which was bullish until the middle of 2000, reversed trends to become bearish towards the second half of the year (Brunnermeier and Nagel, 2004; Ofek and Richardson, 2003). This figure also shows that beyond the up-and-down, short-term market variations inherent to any financial market, a very significant and much deeper trend reversal took place during this period. This market duality (i.e. the bubble and subsequent crash) thus provides a particularly interesting setting for investigating our research question.

\section{Dependent and Independent Variables}

Alliance formation. To test our hypotheses, we took a standard dyadic approach to alliance formation (Gulati and Gargulio, 1999; Hagedoorn and Schakenraad, 1994), wherein, for a given year, the dependent variable is the probability of an alliance between two software organizations. The process of alliance formation is a matching process in which the variables of both alliance partners interact. The variable thus takes the value 1 when an alliance is observed and 0 otherwise.

Status similarity. We follow Jensen (2004) by using as our measure for status the amount of sell-side analyst coverage. The evaluation of publicly traded organizations' performance is mediated by sell-side financial analysts, who have both privileged access to organizations and sufficient time to process information. These analysts decide which organizations are worthy of their attention, and their opinion significantly influences other actors' decisions (Brown, 1993; Groysberg, 2010; Groysberg et al., 2008; McNichols and O'Brien, 1997; Womack, 1996; Zuckerman, 1999). Because high-status organizations hold more prominence and greater visibility than their low-status peers (Podolny, 1993), they usually command enormous attention from the media, the public, 
and other actors, whereas their lower-status counterparts tend to be ignored (Goode, 1978; Gould, 2002). Financial analyst coverage is therefore consistent with a conception of status as proportional to the amount of recognition an actor receives (Bonacich, 1987; Bothner et al., 2010; Podolny, 2005) and provides a reliable sign of recognition by intermediaries who shape audiences' perception of an organization (Zuckerman, 1999). In the context of this study, analyst coverage is preferred to an eigenvector centrality measure of the position of an organization in the alliance network because our dependent variable focuses on the formation of a single tie, whereas eigenvector centrality is a function of the number of ties an organization has formed.

The data used to construct the measure of status come from the historical recommendations database of the Institutional Brokers' Estimate System (IBES). Because the extent of coverage by industry analysts confers status to an organization independent of the positive or negative nature of the coverage it receives, we considered a measure of an organization's status to be the number of reports and recommendations issued by analysts during the three years prior to the analysed period. We thus obtained a score of status for each organization in our sample and for each year within the observation period. We refer to the extent to which two organizations are similar in status as status similarity. Status similarity is operationalized as the ratio of the smaller status score to the larger status score, in a dyad of potential alliance partners (Meuleman et al., 2010; Rosenkopf and Padula, 2008).

Market uncertainty. Following Beckman et al. (2004), we use market volatility to measure the extent of market uncertainty. We used data from the Dow Jones Software Index and constructed our measure of volatility by calculating the mean monthly volatility of the Dow Jones Software Index for each year.

\section{Control Variables}

Size. We included organizational size as a control in our models for two reasons. First, although size and status refer to two different concepts, an organization's size may partly correlate to its status. Second, in the software industry, the utility of a product or service increases with the number of its users, a property known as network externality (Samuelson, 1951; Shapiro, 1985; Shapiro and Varian, 1999; Shy, 2001). As a result of network externalities, the prospect of an alliance between two potential partners increases as the size of their joint pool of clients grows. We take the sum of the total sales of each pair of potential alliance partners as a proxy for the size of the organization.

Resources complementarity. This is a key driver in the formation of alliances (Gulati and Gargulio, 1999; Rothaermel and Deeds, 2006; Wang and Zajac, 2007). Prior research has identified critical resources that enhance the probability of alliance formation between two organizations, including financial resources, R\&D resources, human resources, and technological resources (Gulati and Gargulio, 1999; Gulati and Westphal, 1999; Gulati et al., 2009; Lavie, 2007; Powell et al., 2005). We collected data from COMPUSTAT on cash funds for financial resources, R\&D intensity for $R E D$ resources, and number of employees for human resources. These three resources complementarity 
variables are operationalized as the absolute value of the difference between the resources of the dyad members. For technological resources complementarity, we built a vector of binary variables $t_{j}$ that describes the subsectors in which each firm $j$ operates. On the basis of a review of industry classifications (i.e. from the US Census Bureau, the Organisation for Economic Co-operation and Development, the European Technology Observatory, and the International Data Corporation), we divided the industry into five subsectors: user applications, databases, application development, system infrastructure, and operating systems. For example, for a firm $n$ that is involved in system infrastructures and operating systems to the exclusion of other sections, its technology vector is $t_{n}=(0,0,0,1,1)$. For a firm $j$ that is involved in application development and system infrastructure, its technology vector is $t_{n}=(0,0,1,1,0)$. Technological complementarity between $n$ and $j$ is measured by the product $t_{n}^{\prime} \cdot C \cdot t_{j}$ where $C$ is a symmetric matrix of dichotomous variables mapping complementary subsectors. ${ }^{\left[{ }^{[2]}\right.}$ Because size is associated with the number of subsectors in which an organization operates, the measure is normalized to remove the effect of size, by dividing $t_{n}^{\prime} \cdot C \cdot t_{j}$ by the Euclidian norm of $t_{n}$ and $t_{\text {. }}$

Service orientation. In the software industry, two distinct activities coexist: product-oriented activities and service-oriented activities (Campbell-Kelly, 1995, 2004; Cusumano, 2003, 2004). Consequently, we included in our models the service orientation of the dyad as an additional control variable to take into account any potential difference in the incidence of alliance formation. We used service orientation to refer to the extent to which an organization's business centres on the development and sales of software services, as opposed to software products. In public disclosure documents, such as 10-K SEC filings, software organizations report their sales using product and service categories. The service orientation of an organization is therefore calculated as follows: for a firm selling $\$ 70$ million of services and $\$ 30$ million of products, the service orientation is $70 /(30+70)=0.70$. We thus define the service orientation of a dyad as the product of the service orientation of both its organizations.

Network proximity. Organizations rely on their existing networks of alliance partners both to access crucial information regarding the competencies and needs of potential partners and to overcome the paucity of information regarding potential partners' capabilities, needs, and behaviours (Gulati, 1995a, 1995b; Gulati and Gargulio, 1999; Nohria, 1992). As the distance increases between two organizations in the network of alliances, the probability decreases that they will obtain information regarding each other. The distance between two organizations is measured as the number of steps separating the two organizations in the alliance network. A network proximity variable is defined as the inverse of distance. It takes the value 0 when no path exists. We followed previous studies and used a five-year moving window to determine how far back prior alliances should be considered relevant (Gulati and Gargulio, 1999; Rosenkopf and Padula, 2008). Because little information is available on alliance duration, the model was also run with a three-year window. Regression results are not dependent on the size of the moving window. 
Alliance experience, geography, and media coverage. Organizations that have entered into multiple alliances tend to use more effective ways to enter into new collaborations (Gulati and Gargulio, 1999; Rosenkopf and Padula, 2008). We therefore included an alliance experience variable, operationalized as the product of the number of alliances entered into by each of the two potential partners using the same three-year moving window used for the network proximity variable. Although the software industry has historically been centred in the United States, the formation of alliances may have a geographical dimension. A dummy variable indicates whether two organizations are located in the same region (i.e. Europe, Asia, or North America). The geography variable is set to 1 when the two members of a dyad have their headquarters in the same region and 0 otherwise. The media coverage of an organization may also influence the willingness of others to associate with it. We measured media coverage by counting the number of articles in which a focal organization was mentioned during the previous year. Media coverage data for each organization were collected from Factiva. ${ }^{[3]}$ The media coverage for a dyad was computed as the product of the media coverage of the two organizations composing the dyad.

\section{Statistical Model}

To study the potential dyads that can enter an alliance each year, we followed a standard dyad approach used in studies of tie formation (Gulati and Gargulio, 1999). Each observation in our analysis describes a pair of organizations; the dependent variable of interest (for the $i j$ pair) is coded 1 when an alliance was formed between organization $i$ and organization $j$ at time $t$, and 0 when an alliance was not formed. The number of alliances formed relative to the total number of dyads is very small. Consequently, a random sampling of dyads would yield downward-based estimates because the average probability of alliance formation is small (0.008) (King and Zeng, 2001). Consequently, we followed Sorenson and Stuart (2008) and used a conditional logit model, wherein each (case + control) group is a stratum. A logistic regression model is specified for each stratum:

$$
\pi_{k}(\mathbf{x})=E\left(Y_{k} \mid \mathbf{x}\right)=\frac{e^{\alpha_{k}+\beta \mathbf{x}}}{1+e^{\alpha_{k}+\beta \mathbf{x}}}
$$

$\pi_{k}(\mathbf{x})$ is the conditional mean of our dependent variable $Y_{k}$ which takes the value 1 for the case and 0 for the controls in the group; $x$ is a vector of covariates, and $\alpha_{k}$ is the contribution of the logit of all terms constant within the strata (Hosmer and Lemeshow, 2000). Matched case-control sampling was done in the following way: for each observed alliance, we selected randomly five control dyads in the same year, for which no alliance occurred. Further increasing the number of control dyads would have only marginally increased the efficiency of the estimates (Taylor, 1986). Because our controls are matched on year, the value of volatility, our measure of market uncertainty, does not vary from dyad to dyad within a (case + controls) stratum. Consequently, the main effect of volatility is included in the intercepts of each stratum, and thus is not estimated.

To contrast the up market and down market, we split our sample into two subsamples. The first sub-sample represents the results for the period that preceded the 
crisis, up to the middle of 2000 (i.e. the bubble period). The second sub-sample represents the results for the time period that followed the crisis, until 2002 (i.e. the postbubble period). We prefer this method, which keeps the interpretation of the results straightforward, over the alternative method of tracking the interaction of an up/down market dummy variable with the interaction variable status similarity $\times$ market uncertainty in a non-linear model.

\section{RESULTS}

Table I presents descriptive statistics of the variables in the analysis for the whole dataset. Table II presents the result of the regressions for the different models and is divided into two parts: the first set of columns (Models 1 to 3) presents the results for the expansion phase, and the second set of columns (Models 4 to 6) presents the results for the contraction phase. Because the baseline probability of alliance formation between two organizations is low (0.008), the odds ratios given by the conditional logistic regression model are good approximations of probability ratios (Norton et al., 2004). For this reason, we interpret our results in terms of probability ratios, which are more intuitive than odds ratios. By contrast with marginal effects, probability ratios do not depend on the value of other covariates (Hoetker, 2007; Wiersema and Bowen, 2009).

Because the addition of variables does not modify the conclusions that can be drawn from our models, we discuss directly Model 3 and Model 6. As expected, size has a positive effect on the probability of alliance formation. One standard deviation of our size variable for the dyad increases the probability of alliance formation by 5 per cent $\left(\approx \mathrm{e}^{1.018 \times 0.05}\right)$ in Model 3 (i.e. the up market) and 4 per cent in Model 6 (i.e. the down market). Overall, the effect of size is small, which was not entirely unexpected. Large organizations may indeed benefit from innovations originating in small organizations, and small organizations may benefit from access to the larger organizations' cash, distribution, and marketing capabilities. Financial resources complementarity has a positive effect only in a down market. In an up market, having access to financial resources may be unproblematic, while in a more difficult market, it may constitute a valuable asset. R\&D resources complementarity has a positive effect in an up market, indicating that organizations that have invested heavily in research are deemed valuable collaborative partners. In a down market, by contrast, R\&D resources complementarity has a negative effect, indicating the smaller interest for promising yet uncertain technology. Technological complementarity is not significant, which suggests that alliances may have been driven by rapidly changing market demands that cut across the five subsectors previously identified. Human resources complementarity is also not significant. The models also show that service orientation has no primary effect and that serviceoriented dyads are no more likely than product-oriented dyads to enter alliances.

We find that alliance experience has a positive and significant influence on alliance formation only in a down market (i.e. in Model 6). For one standard deviation, the probability of an alliance increases by roughly 15 per cent $\left(\mathrm{e}^{4.834 \times 0.03} \approx 1.15\right)$. In an up market (i.e. in Model 3), however, the effect is not significant. This difference between up and down markets may be explained by a lack of concern for the amount of resources necessary to manage alliances and their afferent risks in up markets. Network proximity 


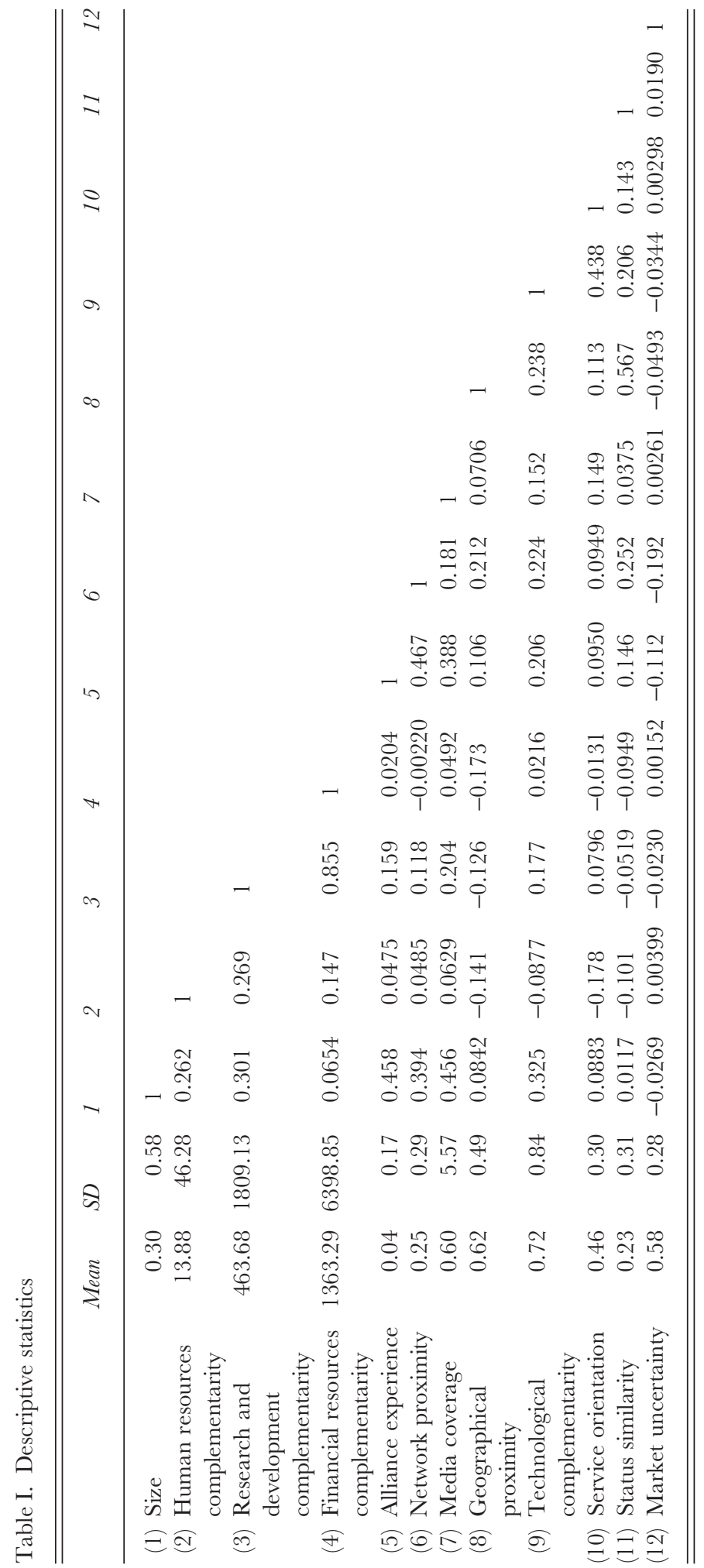




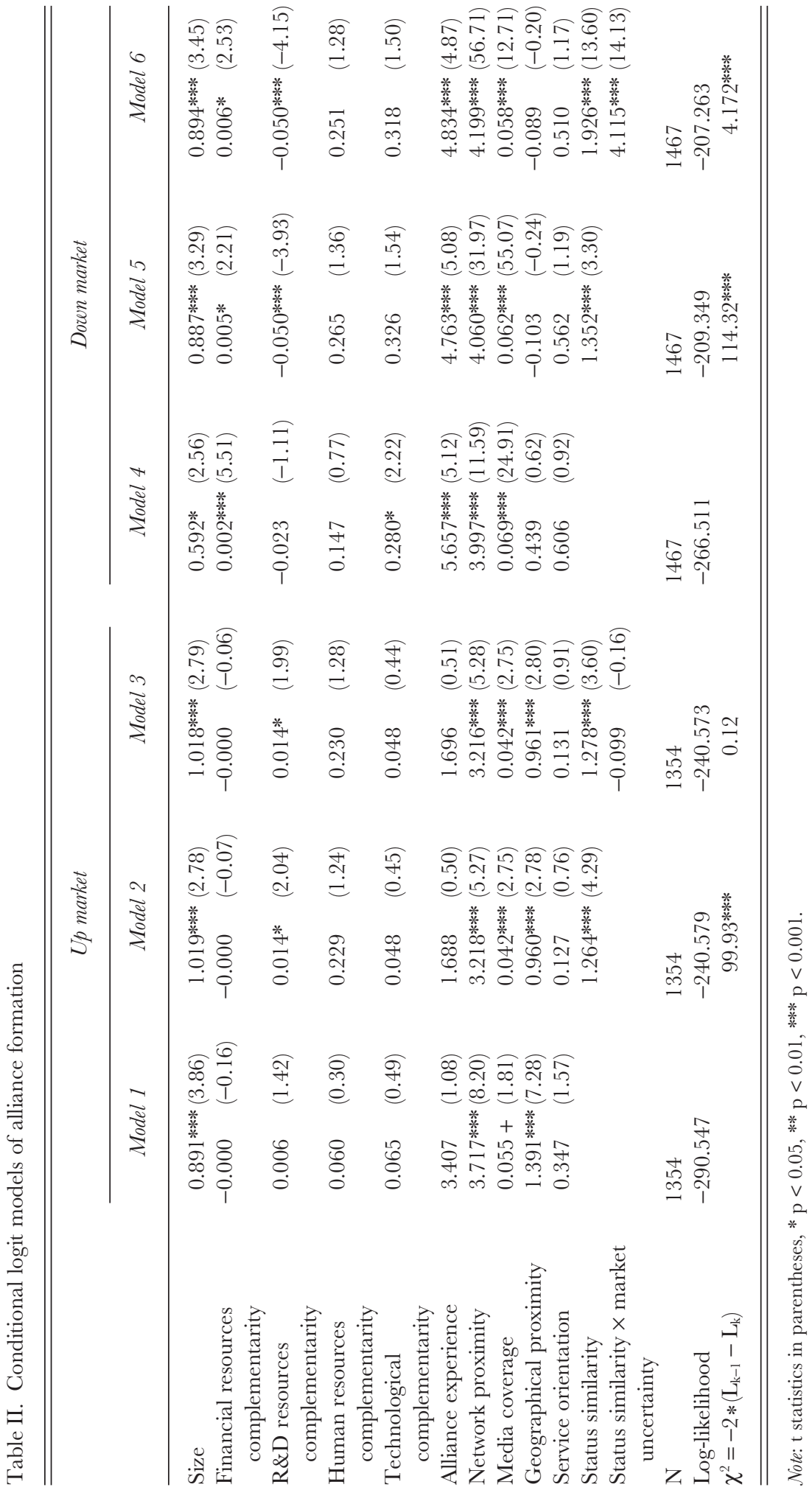

(C) 2013 John Wiley \& Sons Ltd and Society for the Advancement of Management Studies 
has a significant impact on alliance formation in both up and down markets. For example, in an up market, when two organizations are directly connected through a prior alliance, the probability of a new alliance is 4.85 times greater than the probability of an alliance between two organizations at distance $2\left(\approx \mathrm{e}^{3.162}\right)$; when no previous path exists between the two organizations in the alliance network, the probability is about 24 times smaller than when a prior direct link exists. We also find that media coverage matters. For one standard deviation of this variable, the probability of alliance formation increases by 3 per cent in the up market (i.e. in Model 3). Effect size is comparable in the down market. Finally, the coefficient for the geography variable is significant only in the up market.

\section{Hypotheses Testing}

To test whether our hypotheses were supported, we used a simulation-based approach proposed by Zelner (2009), in which the distribution of the coefficient estimates obtained from the conditional logit is simulated directly by repeatedly drawing new values of these estimates from the normal distribution. Thus, we calculated simulated predicted probability ratios that give us an interval of confidence of our predictions.

Using this simulation method, we summarize graphically the relationship between status similarity and the probability of alliance formation in up and down markets at different levels of market uncertainty in Figure 2. In this figure, we took, as a baseline probability, the probability ratio of tie formation for one standard deviation of status similarity at the minimum level of uncertainty.

The results provide support for our hypotheses. Hypothesis 1 stated that status homophily is greater in a down market than in an up market. Indeed, the probability

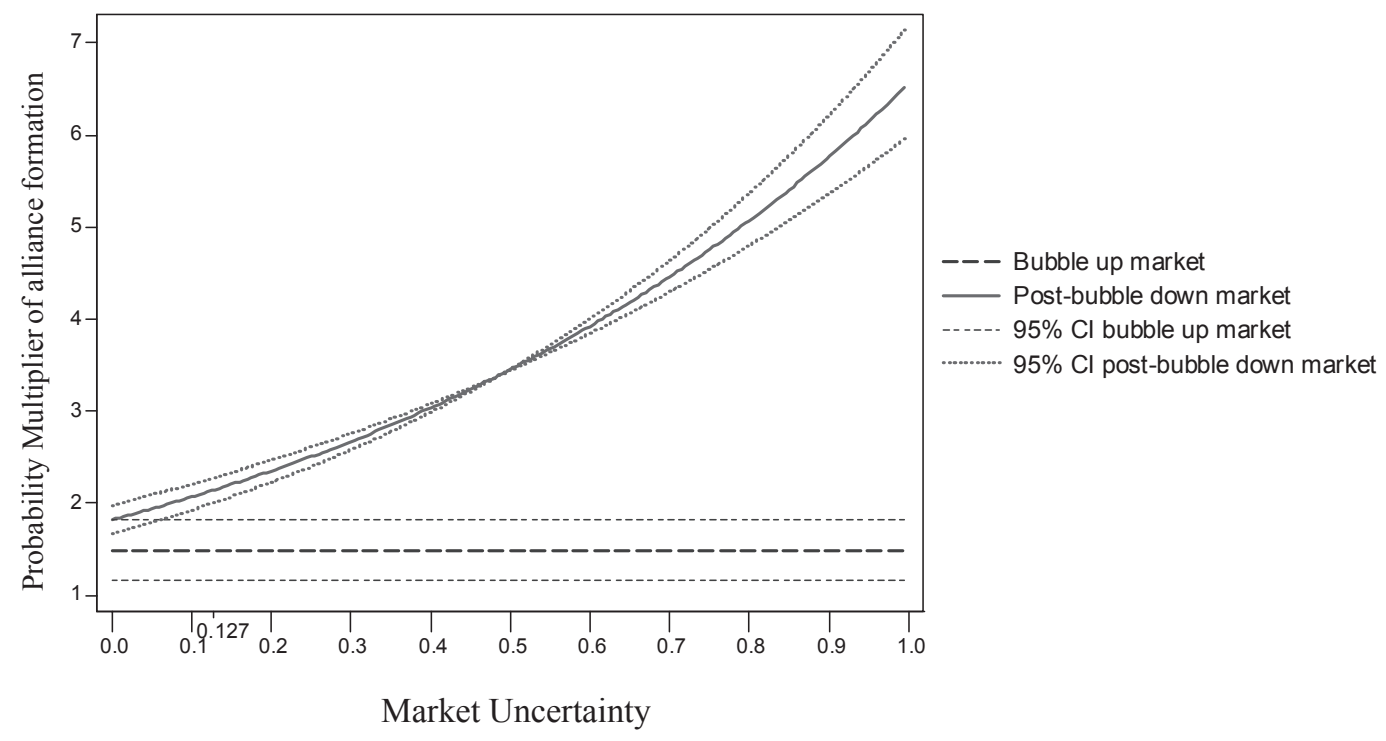

Figure 2. Probability multiplier of alliance formation for one standard deviation of status similarity Notes: CI = confidence interval; 0.127 marks the minimum level of observed market uncertainty. 
multiplier for one standard deviation of status similarity is greater for all observed values of market uncertainty. The smallest observed value of market uncertainty is 0.127 ; for this value, the highest value of the probability ratio in the up market is less than the lowest value of the probability ratio in the down market within the 95 per cent interval of confidence. The difference increases further for higher levels of market uncertainty. Second, in the down market, the increase in the probability multiplier for one standard deviation of status is positive when market uncertainty increases, but no such relationship is observed in the up market in which the probability multiplier for one standard deviation of status similarity does not vary with market uncertainty. This finding therefore provides support for Hypothesis 2, which predicted such difference in the formation of status homophilous ties between an up market and a down market.

\section{Robustness Checks}

In addition to the models reported here, we conducted several robustness checks. First, we built an alternative measure of status by multiplying the number of analysts who covered the firm by the average score of analysts' evaluations (ranging from 0 to 1), as calculated by Thomson Reuters in the IBES database. This measure takes into account both the amount of coverage and the positive or negative nature of the recommendations.

We also used a different estimation procedure to take into account a potential bias associated with sample truncation and the presence of unobserved heterogeneity. Our data cover 95 per cent of market capitalization, which excludes a large number of small firms, including firms that are not publicly traded (e.g. pre-IPO private firms that were created during the internet bubble and constituted alliance partner targets). Our sample is therefore truncated by size and, because of the positive correlation between status and size, the implication is that, compared with the overall population, our sample has a lower proportion of dyads with low-status homophily. ${ }^{[4]}$ This truncation may bias our estimates if an unobserved variable is associated with the probability of inclusion in the sample even when this unobserved variable is uncorrelated with our explanatory variable in the overall population (Achen, 1986; Sartori, 2003) because a sample truncation induces a correlation between the unobserved variable and the explanatory variable. Further, if an unobserved variable is correlated with our explanatory variable, independent of its effect of inclusion of the sample, the estimates will be also biased. To address this possible bias, we ran mixed logit models (mixlogit in Stata). A mixed logit model comprises random coefficients multiplied by the explanatory variables of interest (Train, 2003). These random coefficients can be correlated with the error term to correct for correlation between the explanatory variable and the error term. We specified a model in which we added random coefficients to our fixed coefficients for the following variables: (a) status homophily, and (b) the interaction between status homophily and market uncertainty. We obtained similar results to our conditional logit models, thus confirming the robustness of our findings.

\section{DISGUSSION}

Status is an important feature of market dynamics and holds particular relevance in uncertain contexts (Podolny, 1994, 2005). Our purpose in this study was to investigate 
the contingent value of status in the alliance partner-selection process, by showing the context-dependent nature of the relationship between uncertainty and status homophily in the formation of strategic alliances. This study therefore sensitizes us to how different framings of uncertainty affect the relative attention paid to status cues when selecting an alliance partner. Our findings have important implications for our understanding of status-based models of market interactions and more broadly for research on strategic decision making under uncertainty.

\section{The Contingent Value of Status Signals}

Prior status research has widely assumed that the greater the market uncertainty, the greater the role of status in the formation of alliances and partnerships, an assumption that has been amply verified by research documenting the formation of statushomophilous ties in the context of uncertainty (Chung et al., 2000; Podolny, 1994). In this study, we challenge this assumption and instead suggest a more fine-grained perspective on the relationship between market uncertainty and status homophily, based on the idea that the subjectivity inherent in quality judgments gives rise to different framings of uncertainty that are linked to the context in which organizations are embedded.

As predicted in Hypothesis 1, we find that when organizations are primarily concerned with missing high-potential investment opportunities, they will focus on upside risk and thus initiate heterophilous ties. By contrast, when organizations are mainly concerned with forming alliances that may damage their status or fail to bring tangible benefits (i.e. downside risk), they will rely on more conservative formulas when selecting a partner, thus leading to the formation of homophilous ties. Consistent with Hypothesis 2, we also find that an increase in market uncertainty has a positive effect on the level of status homophily in a down market but no effect in an up market, with a probability ratio as much as five times higher in a down market than in an up market for one standard deviation of status homophily. These findings therefore advance the theory of statusbased models of interactions by emphasizing the contingent value granted to status when selecting an alliance partner.

Alternatively, the phenomenon may be interpreted as indicating that actors may not only value status differently but also interpret it differently. In an up market, where uncertainty runs high but risk is positively valenced, status is interpreted as a proxy for bargaining power and used by high-status organizations as a means for extracting superior rents from low-status partners interested in gaining recognition (Castellucci and Ertug, 2010). By contrast, when the market trend reverts, and risk becomes negatively valenced, organizations will rely on status cues as a proxy for the quality of potential partners, thereby limiting the probability of failure and the afferent negative signals sent to other actors. These contrasting interpretations will, in turn, lead to opposite interorganizational dynamics, favouring the formation of status homophilous ties in down markets while giving precedence to status heterophilous ties in up markets.

Our empirical setting therefore illustrates how situational elements may impact organizations' use and interpretations of the heuristics they rely upon in the formation of inter-organizational ties. Depending upon which concern prevails and how uncertainty is framed, status signals are granted differentiated value or meaning, which subsequently 
affects an organization's decision to rely on status homophilous or heterophilous ties. Thus, to further our understanding of the relationship between status signals and uncertainty, a contingent perspective on the value of status signals is needed. For instance, future studies could investigate the impact of different contextual factors on how status cues are valued to determine which status characteristics matter and when they matter. As an actor's status is usually defined by the possession of specific attributes (Jasso, 2001; Ridgeway and Berger, 1986) or by the social standing of the actor's exchange partners (Gould, 2002), it would be interesting to investigate when attribute-based status cues are preferred over relation-based status cues. Future research could also explore how organization-specific factors may shape the routines that inform how an organization deals with status signals. Although the value and interpretation of status cues is widely assumed to be uniform across actors, it may actually vary, depending on the selective coding of information at the level of the individual organization. Exploring the different processes through which an organization learns to deal with status signals and how these processes lead to different strategic behaviours could further inform us regarding the contingent value of status.

\section{The Role of Context in Decision Making under Uncertainty}

This study also furthers our understanding of organizational decision making under uncertainty, both by casting light on the under-appreciated role of situational elements in framing and shaping organizational behaviour and by providing insights into the differentiated uncertainty-mitigation mechanisms that organizations rely on when selecting an alliance partner. Although prior research has emphasized the reference-dependent nature of organizations' behaviour and, in so doing, has deepened our understanding of the contingent nature of decision-making processes, it has largely neglected the impact of context on decision making and framing (Gavetti et al., 2007). Consistent with recent 'neo-Carnegie' research on attention (Gavetti et al., 2007, 2012; Joseph and Ocasio, 2012; Ocasio, 1997), we argue that market conditions can be construed as frames that shape organizations' sensemaking processes (Fossett, 2011) and behaviours, and we empirically show how two market conditions frame strategic decision making under uncertainty in an alliance partner-selection process.

Prior research that examined the responses organizations develop when facing uncertainty (DiMaggio and Powell, 1983; Haunschild, 1994; Pfeffer and Salancik, 1978) has often conceptualized it as high or low environmental instability (Chung et al., 2000) or as a continuum between these two states (Reed et al., 1996). In contrast to these studies, this article distinguishes between the level of uncertainty experienced by organizations and the differentiated framing of this uncertainty as it may translate into an emphasis on downside or upside risk. Our findings show that being embedded in different market conditions will lead organizations not only to differently frame the uncertainty they confront and attend to different concerns but also to mobilize differently the information available to them.

Specifically, our quasi-experimental setting (i.e. the internet bubble and its subsequent crash) allows us to empirically capture a shift in the way information available to organizations is processed, understood, and mobilized in the decision-making process. First, as previously discussed, the impact of context can be observed in the way heuristics, 
such as status cues, are differently valued and interpreted by organizations seeking to mitigate the uncertainty they confront. Second, these situational elements also impact the scope of signals that will be considered in the decision-making process. For instance, although prior alliance experience and financial resources complementarities are heavily relied upon in the down market condition, they are not significant in the up market condition. In contrast, geographical proximity, which was considered as interesting information in the up market condition, is considered as a significantly less meaningful source of information in the down market condition.

These findings suggest that although organizations may jointly employ multiple mechanisms to mitigate uncertainty, depending on how they frame this uncertainty, they will typically give precedence to one mechanism. In a context where uncertainty is positively valenced (i.e. framed as upside risk), organizations will tend to rely on more open and inclusive mitigation mechanisms, in an effort to avoid missing good opportunities. In contrast, in a context where uncertainty is negatively valenced (i.e. framed as downside risk), organizations will adopt more conservative and exclusive uncertaintymitigation mechanisms, in an effort to avoid making bad deals.

By providing insights into the nature of the concerns faced by organizations when selecting an exchange partner and how the uncertainty-mitigation mechanisms they subsequently deploy differ substantially as a function of the market conditions, we therefore contribute to a qualitative approach to uncertainty (Beckman et al., 2004; Milliken, 1987; Podolny, 2001; Yasai-Ardekani, 1986) that emphasizes how variations in the nature of uncertainty can alter organizations' prevailing logic of decision making (Beckman et al., 2004; Gulati and Higgins, 2003). Future research should therefore be directed towards examining the importance of framing on the strategies deployed to mitigate uncertainty. For instance, prior research dealing with decision-making processes under uncertainty has generally assumed similar effects of market uncertainty across all market participants. Although Beckman et al. (2004) discuss uncertainty unique to an organization (i.e. firm-specific uncertainty), largely neglected is the question of how market uncertainty - which is common to all actors - may differently affect organizations. In this regard, further research could investigate whether heterogeneity exists in the way individual organizations confront market uncertainty and, if so, how this heterogeneity can affect these organizations' propensity to give precedence to one uncertainty-mitigation mechanism over another.

\section{Limitations of the Study and Concluding Remarks}

Despite these contributions, some limitations of this study deserve mention. First, the responses of individual organizations were not observed directly. The dependent variable is an event occurring at the dyad level. Our approach is justified because tie formation is a key phenomenon in research status. Future research should, however, also investigate the behaviour of individual organizations, rather than tie formation, as done, for instance, by Phillips and Zuckerman (2001). Second, although we focus exclusively on dyadic relationships, organizations may form alliances with multiple partners. It is possible that an organization's extant pattern of ties may positively or negatively affect its willingness to initiate heterophilous ties, independent from the context in which the firm 
is embedded. Future research could therefore address how an organization's alliance portfolio affects the value granted to status signals in subsequent alliance formation. Additionally, while the number of analysts covering an organization has been used as a measure of the status of an organization in prior studies (Jensen, 2004), not all analyst reviews carry the same weight. Since 1972, Institutional Investor Magazine has published the 'All-American Research Team' ranking, which lists so-called 'star analysts' (Groysberg, 2010), whose opinions carry more weight than those of their peers. Thus, the status of an organization may be greater when it has been reviewed by star analysts than by a random sample of analysts. Our data do not identify each analyst by name and, thus, preclude the ability to construct a weighted measure of analyst coverage. Thus, an interesting approach in future research would be to consider the prestige of the statusconferring audience in developing measures of an organization's status. Third, although our study is not likely to suffer from a cultural bias due to the heavy US-centric nature of our sample, uncertainty may not elicit the same responses in all cultures, and, therefore, the heuristics and signals actors rely on to cope with uncertainty may differ. We thus highlight this consideration for scholars when determining their future research settings. Finally, it would be interesting to consider the framing of uncertainty among actors in a more fine-grained fashion. Because we are dealing with the burst of a speculative bubble, we suspect that the change of frame is abrupt and adequately captured by our dichotomous variable. However, building a more refined view of frames could be helpful to further our understanding of how actors may differently respond to the uncertainty they confront. Such a perspective could be achieved by analysing the discourses used by actors after each significant up or down market variation.

In conclusion, this study makes an important step towards developing our understanding of the relationship between market uncertainty and the role of status in the formation of strategic alliances. We develop a contingent perspective on the value of status by empirically examining how different market conditions affect organizations' emphasis on status cues when responding to market uncertainty. When organizations are primarily concerned with not missing good opportunities, they tend to initiate status heterophilous ties. By contrast, when their primary concern is to avoid making bad decisions, organizations respond to market uncertainty by forming status homophilous ties. Our results suggest that the contingent value of status signals should be further investigated, both to advance our understanding of the role of status in the formation of alliances and to call for a more fine-grained approach to strategic decision making under uncertainty.

\section{ACKNOWLEDGMENTS}

We would like to thank Donald Bergh for his great editorial guidance and the three anonymous reviewers for their insightful, constructive, and rigorous feedback. We are grateful to Jean-Philippe Bonardi, Rodrigo Canales, Xavier Castañer, and Daniela Lup for their thoughtful critical reviews and suggestions in the development of our paper. Finally, we are grateful to Olga Bruyaka, without whom this article would likely not have happened.

\section{NOTES}

[1] The neo-Carnegie perspective, as proposed by Gavetti et al. (2007), has three basic objectives: (1) to pay more attention to elements in the initial formulation of BTF that have been neglected; (a) decision 
making and (b) hierarchy, communication structures, and conflicts; (2) to incorporate advances in conceptions of individual behaviour in contemporary psychological and sociological research; and (3) to assess the linkages among the fundamental elements in BTF's theoretical structure. This study is particularly concerned with organizational attention, which relates to point 2. Note that attention-based research does not limit itself to the importance of context or situation in influencing attention and, thereby, influencing organizational behaviour but that it also considers the principle of 'structural distribution of attention', which refers to the influence of institutions and cultural factors (Thornton and Ocasio, 1999; Thornton et al., 2012).

[2] The coding of the complementary matrix and the number of dimensions is based on a review of industry classifications and discussions with two industry experts. Of course, the coding of complementarity into a binary variable remains partially arbitrary; however, proximate codings have given similar results.

$$
C=\left[\begin{array}{llllll}
1 & & & & \\
1 & 1 & & & \\
0 & 1 & 1 & & \\
1 & 0 & 1 & 1 & \\
0 & 0 & 1 & 1 & 1
\end{array}\right] .
$$

[3] This count was done under the category 'Major News Sources and Business Publications'.

[4] The precise reason is the following: because small firm are excluded, two types of dyads are underrepresented in our sample: (1) (high-status, low-status) dyads for which status homophily is low; and (2) (low-status, low-status) dyads for which status homophily is high. As a result, compared with the overall population, our sample has a lower proportion of dyads with low-status homophily.

\section{REFERENGES}

Achen, C. H. (1986). The Statistical Analysis of Quasi-Experiments. Berkeley, CA: University of California Press.

Argote, L. and Greve, H. R. (2007). 'A behavioral theory of the firm. 40 years and counting: introduction and impact'. Organization Science, 18, 337-49.

Auster, E. R. (1992). 'The relationship of industry evolution to patterns of technological linkages, joint ventures, and direct investment between US and Japan'. Management Science, 38, 778-92.

Baum, J. A. C., Shipilov, A. V. and Rowley, T. J. (2003). 'Where do small worlds come from?'. Industrial and Corporate Change, 12, 697-725.

Beckert, J. (1996). 'What is sociological about economic sociology? Uncertainty and the embeddedness of economic action'. Theory and Society, 25, 803-40.

Beckman, C. M., Haunschild, P. R. and Phillips, D. J. (2004). 'Friends or strangers? Firm-specific uncertainty, market uncertainty, and network partner selection'. Organization Science, 15, 259-75.

Benjamin, B. A. and Podolny, J. M. (1999). 'Status, quality and social order in the California wine industry'. Administrative Science Quarterly, 44, 563-89.

Bonacich, P. (1987). 'Power and centrality: a family of measure'. American fournal of Sociology, 92, $1170-82$.

Bothner, M. S., Godart, F. C. and Lee, I. W. (2010). What Is Social Status? Comparisons and Contrasts with Cognate Concepts. Working Paper. Berlin: ESMT.

Brown, L. D. (1993). 'Earnings forecasting research: its implications for capital markets research'. International Fournal of Forecasting, 9, 295-320.

Brunnermeier, M. K. and Nagel, S. (2004). 'Hedge funds and the technology bubble'. Fournal of Finance, 59, 2013-40.

Burt, R. S. (2005). Brokerage and Closure: An Introduction to Social Capital. Oxford: Oxford University Press.

Campbell-Kelly, M. (1995). 'Development and structure of the international software industry'. Business and Economic History, 24, 73-110.

Campbell-Kelly, M. (2004). From Airline Reservation to Sonic The Hedgehog. Cambridge, MA: MIT Press.

Cassidy, J. (1999). 'The woman in the bubble: how Mary Meeker helps internet entrepreneurs become very rich'. The New Yorker, 26 April, 48-66.

Cassidy, J. (2002). Dot.con. London: Penguin Books.

Castellucci, F. and Ertug, G. (2010). 'What's in it for them? Advantages of higher-status partners in exchange relationships'. Academy of Management fournal, 53, 149-66.

Christensen, C. M. (1997). The Innovator's Dilemma: When New Technologies Cause Great Firms to Fail. Cambridge, MA: Harvard Business Press.

Christensen, C. M. (2000). 'A better way to break up Microsoft'. Information Week, 769, 122-4. 
Christensen, C. M., Verlinden, M. and Westerman, G. (2002). 'Disruption, disintegration and the dissipation of differentiability'. Industrial and Corporate Change, 11, 955-93.

Chung, S., Singh, H. and Lee, K. (2000). 'Complementarity, status similarity and social capital as drivers of alliance formation'. Strategic Management fournal, 21, 1-22.

Cusumano, M. A. (2003). Managing Product and Services in Software and Other Business. Cambridge, MA: MIT Centre for e-business Research Brief, August, 1-5.

Cusumano, M. A. (2004). The Business of Software: What Every Manager, Programmer and Entrepreneur Must Know to Thrive and Survive in Good Times and Bad. New York: Simon and Schuster International.

Cyert, R. M. and March, J. G. ([1963] 1992). A Behavioral Theory of the Firm. Cambridge, MA: Wiley Blackwell.

Davis, G. F. and Greve, H. R. (1997). 'Corporate elite networks and governance changes in the 1980s'. American fournal of Sociology, 103, 1-37.

DiMaggio, P. and Powell, W. W. (1983). 'The iron cage revisited: institutional isomorphism and collective rationality in organizational field'. American Sociological Review, 48, 147-8.

Docking, D. S. and Koch, P. D. (2005). 'Sensitivity of investor reaction to market direction and volatility: dividend change announcements'. Fournal of Financial Research, 28, 21-40.

Fiegenbaum, A. and Thomas, H. (1986). 'Dynamic and risk measurement perspectives on Bowman's risk-return paradox for strategic management: an empirical study'. Strategic Management fournal, 7, 395-407.

Fiegenbaum, A. and Thomas, H. (1988). 'Attitudes toward risk and the risk-return paradox: prospect theory explanations'. Academy of Management fournal, 31, 85-106.

Fiegenbaum, A., Hart, S. and Schendel, D. (1996). 'Strategic reference point theory'. Strategic Management fournal, 17, 219-35.

Fiss, P. C. and Zajac, E. J. (2006). 'The symbolic management of strategic change: sensegiving via framing and decoupling'. Academy of Management fournal, 49, 1173-93.

Fombrun, C. and Shanley, M. (1990). 'What's in a name? Reputation building and corporate strategy'. Academy of Management Fournal, 33, 233-58.

Fossett, M. (2011). 'Generative models of segregation: investigating model-generated patterns of residential segregation by ethnicity and socioeconomic status'. Fournal of Mathematical Sociology, 35, 114 45.

Gargiulo, M. (1993). 'Two-step leverage: managing constraint in organizational politics'. Administrative Science Quarterly, 38, 1-19.

Gavetti, G., Levinthal, D. and Ocasio, W. (2007). 'Neo-Carnegie: the Carnegie School's past, present, and reconstructing for the future'. Organization Science, 18, 523-36.

Gavetti, G., Greve, H. R., Levinthal, D. A. and Ocasio, W. (2012). 'The behavioral theory of the firm: assessment and prospects'. Academy of Management Annals, 6, 1-40.

Goffman, E. (1974). Frame Analysis: An Essay on the Organization of Experience. New York: Harper and Row.

Goode, W. J. (1978). The Celebration of Heroes: Prestige as a Social Control System. Berkeley, CA: University of California Press.

Gould, R. V. (2002). 'The origins of status hierarchies: a formal theory and empirical test'. American fournal of Sociology, 107, 1143-78.

Greve, H. R. (1999). 'Performance, aspirations, and risky organizational change'. Administrative Science Quarterly, 44, 590-614.

Greve, H. R. (2003). Organizational Learning from Performance Feed-Back: A Behavioral Perspective on Innovation and Change. Cambridge: Cambridge University Press.

Groysberg, B. (2010). Chasing Stars: The Myth of Talent and the Portability of Performance. Princeton, NJ: Princeton University Press.

Groysberg, B., Lee, L. E. and Nanda, A. (2008). 'Can they take it with them? The portability of star knowledge workers' performance'. Management Science, 54, 1213-30.

Gulati, R. (1995a). 'Familiarity breeds trust? The implication of repeated ties on contractual choice in alliances'. Academy of Management foumal, 38, 85-112.

Gulati, R. (1995b). 'Social structure and alliance formation patterns: a longitudinal analysis'. Administrative Science Quarterly, 40, 619-52.

Gulati, R. and Gargulio, M. (1999). 'Where do interorganizational networks come from?'. American Fournal of Sociology, 104, 1439-93.

Gulati, R. and Higgins, M. C. (2003). 'Which ties matter when? The contingent effects of interorganizational partnerships on IPO success'. Strategic Management fournal, 24, 127-44. 
Gulati, R. and Westphal, J. D. (1999). 'Cooperative or controlling? The effect of CEO-boards relations and the contents of the interlocks on the formation of joint ventures'. Administrative Science Quarterly, 44, 473-506.

Gulati, R., Lavie, D. and Singh, H. (2009). 'The nature of partnering experience and the gains from alliances'. Strategic Management Fournal, 30, 1213-33.

Hagedoorn, J. and Schakenraad, J. (1994). 'The effect of strategic technology alliances on company performance'. Strategic Management Fournal, 15, 291-309.

Haunschild, P. (1994). 'How much is that company worth? Interorganizational relationships, uncertainty and acquisition premiums'. Administrative Science Quarterly, 39, 391-411.

Hoetker, G. (2007). 'The use of logit and probit models in strategic management research: critical issues'. Strategic Management fournal, 28, 331-43.

Hogg, M. and Terry, D. (2000). 'Social identity and self-categorization processes in organizational contexts'. Academy of Management Review, 27, 121-40.

Hosmer, D. W. and Lemeshow, S. (2000). Applied Logistic Regression. New York: Wiley.

Jasso, G. (2001). 'Studying status: an integrated framework'. American Sociological Reviewe, 66, 96-124.

Jensen, M. (2004). 'Who gets Wall Street's attention? How alliance announcement and alliance density affect analyst coverage'. Strategic Organization, 2, 293-312.

Jensen, M. (2006). 'Should we stay or should we go? Accountability, status anxiety, and client defections'. Administrative Science Quarterly, 51, 97-128.

Joseph, J. and Ocasio, W. (2012). 'Architecture, attention, and adaptation in the multibusiness firm: General Electric from 1951 to 2001'. Strategic Management Fournal, 33, 633-60.

Kahneman, D. and Tversky, A. (1979). 'Prospect theory: an analysis of decision under risk'. Econometrica: Fournal of the Econometric Society, 47, 263-91.

Keynes, J. M. ([1936] 1958). The General Theory of Interest, Employment and Money. New York: Harcourt Brace.

King, C. and Zeng, L. (2001). 'Logistic regression in rare events data'. Political Analysis, 9, 137-63.

Kogut, B. (1988). 'Joint-ventures: theoretical and empirical perspectives'. Strategic Management Fournal, 9, $319-22$

Kogut, B. (1991). 'Joint ventures and the option to expand and acquire'. Management Science, 37, 19-33.

Lavie, D. (2007). 'Alliance portfolios and firm performance: a study of value creation and appropriation in the US software industry'. Strategic Management Fournal, 28, 1187-212.

Lounsbury, M. (2002). 'Institutional transformation and status mobility: the professionalization of the field of finance'. Academy of Management Fournal, 45, 255-66.

Luo, Y. (1997). 'Partner selection and venturing success: the case of joint ventures with firms in the People's Republic of China'. Organization Science, $\mathbf{8}, 648-62$.

March, J. and Simon, H. (1958). Organizations. New York: Wiley.

March, J. G. and Shapira, Z. (1987). 'Managerial perspectives on risk and risk taking'. Management Science, 33, 1404-18.

McNichols, M. and O'Brien, P. C. (1997). 'Self-selection and analyst coverage'. Fournal of Accounting Research, 35, 167-99.

McPherson, J. M. and Smith-Lovin, L. (1987). 'Homophily in voluntary organizations: status distance and the composition of face-to-face groups'. American Sociological Review, 52, 370-9.

McPherson, M., Smith-Lovin, L. and Cook, J. M. (2001). 'Birds of a feather: homophily in social networks'. Annual Review of Sociology, 27, 415-44.

Meuleman, M., Lockett, A., Manigart, S. and Wright, M. (2010). 'Partner selection decisions in interfirm collaborations: the paradox of relational embeddedness'. Fournal of Management Studies, 47, 995-1019.

Miller, K. D. and Leiblein, M. J. (1996). 'Corporate risk-return relations: returns variability versus downside risk'. Academy of Management fournal, 39, 91-122.

Miller, K. D. and Reuer, J. J. (1996). 'Measuring organizational downside risk'. Strategic Management Fournal, 17, 671-91.

Milliken, F. (1987). 'Three types of perceived uncertainty about the environment: state, effect, and response uncertainty'. Academy of Management Review, 12, 133-43.

Nohria, N. (1992). 'Information and search in creation of new business ventures: the case of the 128 Venture Group'. In Nohria, N. and Eccles, R. G. (Eds), Networks and Organizations. Cambridge, MA: Harvard Business School Press, 240-61.

Norton, E. C., Wang, H. and Ai, C. (2004). 'Computing interaction effects and standards errors in logit and probit models'. Stata fournal, 4, 154-67.

Ocasio, W. (1997). 'Towards an attention-based view of the firm'. Strategic Management Fournal, 18, 187-206.

Ocasio, W. (2011). 'Attention to attention'. Organization Science, 22, 1286-96. 
Ofek, E. and Richardson, M. (2003). 'DotCom mania: the rise and fall and fall of internet stocks'. Fournal of Finance, 58, 1113-38.

Owen-Smith, J. and Powell, W. (2004). 'Knowledge networks as channels and conduits: the effects of spillovers in the Boston biotechnology community'. Organization Science, 15, 5-21.

Owen-Smith, J. and Powell, W. W. (2008). 'Networks and institutions'. In Greenwood, R., Oliver, C., Suddaby, R. and Sahlin-Andersson, K. (Eds), Handbook of Organizational Institutionalism. London: Sage, 594-621.

Park, D. and Podolny, J. M. (2000). 'The competitive dynamics of status and niche width: US investment banking 1920-1949'. Industrial and Corporate Change, 9, 377-414.

Pfeffer, J. and Salancik, G. R. (1978). The External Control of Organizations: A Resource Dependence Perspective. New York: Harper and Row.

Phillips, D. J. and Zuckerman, E. W. (2001). 'Middle status conformity: theoretical restatement and empirical demonstration in two markets'. American fournal of Sociology, 107, 379-429.

Podolny, J. M. (1993). 'A status based model of market competition'. American fournal of Sociology, 98, 829 72.

Podolny, J. M. (1994). 'Market uncertainty and the social character of economic exchange'. Administrative Science Quarterly, 39, 458-83.

Podolny, J. M. (2001). 'Networks as the pipes and prisms of the market'. American Fournal of Sociology, 107, 33-60.

Podolny, J. M. (2005). Status Signals. Princeton, NJ: Princeton University Press.

Podolny, J. M. and Phillips, D. J. (1996). 'The dynamics of organizational status'. Industrial and Corporate Change, 5, 453-71.

Podolny, J. M., Stuart, T. E. and Hannan, M. T. (1996). 'Networks, knowledge, and niches: competition in the worldwide semiconductor industry, 1984-1991'. American Fournal of Sociology, 102, 659-89.

Powell, W. W. and DiMaggio, P. (1983). 'The iron cage revisited: institutional isomorphism and collective rationality in organizational fields'. American Sociological Review, 48, 147-60.

Powell, W. W., White, D. R., Koput, K. W. and Owen-Smith, J. (2005). 'Network dynamics and field evolution: the growth of interorganizational collaboration in the life sciences'. American fournal of Sociology, 110, 1132-205.

Reed, R., Lemak, D. J. and Montgomery, J. C. (1996). 'Beyond process: TQM content and firm performance'. Academy of Management Review, 21, 173-202.

Reuer, J.J. and Leiblein, M.J. (2000). 'Downside risk implications of multinationality and international joint ventures'. Academy of Management foumal, 43, 203-14.

Ridgeway, C. L. and Berger, J. (1986). 'Expectations, legitimation, and dominance behavior in task groups'. American Sociological Review, 51, 603-17.

Rosenkopf, L. and Padula, G. (2008). 'Investigating the microstructure of network evolution: alliance formation in the mobile communications industry'. Organization Science, 19, 669-87.

Rothaermel, F. T. and Deeds, D. L. (2006). 'Alliance type, alliance experience and alliance management capability in high-technology ventures'. Entrepreneurship and Strategic Alliances, 21, 429-60.

Samuelson, P. (1951). Economics. New York: McGraw-Hill.

Sartori, A. E. (2003). 'An estimator for some binary-outcome selection models without exclusion restrictions'. Political Analysis, 11, 111-38.

Shapiro, C. (1985). 'Network externalities, competition, and compatibility'. American Economic Review, 75 , $424-40$.

Shapiro, C. and Varian, H. R. (1999). Information Rules. Cambridge, MA: Harvard Business School Press.

Shinkle, G. A. (2012). 'Organizational aspirations, reference points, and goals'. Fournal of Management, 38, 415-55.

Shipilov, A. V., Li, S. X. and Greve, H. R. (2011). 'The prince and the pauper: search and brokerage in the initiation of status-heterophilous ties'. Organization Science, 22, 1418-34.

Shoham, A. and Fiegenbaum, A. (2002). 'Competitive determinants of organizational risk-taking attitude: the role of strategic reference points'. Management Decision, 40, 127-41.

Shy, O. (2001). The Economics of Network Industries. Cambridge: Cambridge University Press.

Snow, D. A., Rochford, E. B., Worden, S. K. and Benford, R. D. (1986). 'Frame alignment processes, micromobilization and movement participation'. American Sociological Review, 51, 464-81.

Sorenson, O. and Stuart, T. E. (2008). 'Bringing the context back in: settings and the search for syndicate partners in venture capital investment networks'. Administrative Science Quarterly, 53, $266-94$.

Stuart, T. E., Hoang, H. and Hybels, R. C. (1999). 'Interorganizational endorsments and the performance of entrepreneurial ventures'. Administrative Science Quarterly, 44, 315-49. 
Sullivan, B. N. (2010). 'Competition and beyond: problems and attention allocation in the organizational rulemaking process'. Organization Science, 21, 432-50.

Taylor, J. M. G. (1986). 'Choosing the number of controls in a matched case-control study, some sample size, power and efficiency considerations'. Statistics in Medicine, 5, 29-36.

Thornton, P. H. and Ocasio, W. (1999). 'Institutional logics and the historical contingency of power in organizations: executive succession in the higher education publishing industry, 1958-1990'. American Journal of Sociology, 105, 801-43.

Thornton, P. H., Ocasio, W. and Lounsbury, M. (2012). The Institutional Logics Perspective: A New Approach to Culture, Structure, and Process. Oxford: Oxford University Press.

Train, K. E. (2003). Discrete Choice Methods with Simulation. Cambridge: Cambridge University Press.

Tversky, A. and Kahneman, D. (1974). 'Judgment under uncertainty: heuristics and biases'. Science, 185, 1124-31.

Tversky, A. and Kahneman, D. (1981). 'The framing of decisions and the psychology of choice'. Science, 211, 453-8.

Wang, L. and Zajac, E. J. (2007). 'Alliance or acquisition? A dyadic perspective on interfirm resource combinations'. Strategic Management Fournal, 28, 1291-317.

Washington, M. and Zajac, E. J. (2005). 'Status evolution and competition: theory and evidence'. Academy of Management foumal, 48, 282-96.

Wiersema, M. and Bowen, H. (2009). 'The use of limited dependent variable techniques in strategy research: issues and methods'. Strategic Management Fournal, 30, 679-92.

Williams, R. H. and Benford, R. D. (2000). 'Two faces of collective action frames: a theoretical consideration'. Current Perspectives in Social Theory, 20, 127-52.

Womack, K. L. (1996). 'Do brokerage analysts' recommendations have investment value?'. Fournal of Finance, 51, 137-67.

Yasai-Ardekani, M. (1986). 'Structural adaptations to environments'. Academy of Management Review, 11, 9-21.

Zelner, B. A. (2009). 'Using simulation to interpret results from logit, probit, and other nonlinear models'. Strategic Management fournal, 30, 1335-48.

Zuckerman, E. W. (1999). 'The categorical imperative: securities analysts and the illegitimacy discount'. American fournal of Sociology, 104, 1398-438. 